\title{
Lezers reageren
}

\section{Controledoelstellingen en beweringen}

\author{
Prof. J. H. Blokdijk
}

\section{Inleiding}

In het nummer van juli/augustus 1990 van dit blad verscheen een artikel van de hand van J. ten Wolde, getiteld: Controledoelstellingen en beweringen. Daarin introduceert de auteur enkele begrippen die in de Amerikaanse theorie en praktijk van de accountantscontrole de laatste jaren opgeld hebben gedaan. Dit was belangwekkend en verhelderend.

Waarom reageert deze lezer dan, en nog wel zo láát? Omdat het artikel óók enkele beweringen bevat die ertoe kunnen leiden dat controledoelstellingen uit het zicht raken. Dit wil ik gaarne nader toelichten.

\section{Positieve en negatieve controle}

Ten Wolde acht het begrippenpaar 'positieve/ negatieve controle' enigszins verouderd (p. 300); even verder duidt hij de begrippen 'juistheid' en 'volledigheid' aan als 'oud' (schema p. 302). Zoals bekend is de positieve controle gericht op de controledoelstelling 'juistheid' en de negatieve controle op de controledoelstelling 'volledigheid'. Ten Wolde wekt nu, vooral door het schema on p. 302, de indruk genoemde controledoelstellingen te willen vervangen door een zestal andere: bestaan, volledigheid, accuratesse, waardering, eigendom en presentatie.

Ik zou dit betreuren, en wel om de volgende redenen.

Accountantscontrole is onderzoek naar de getrouwheid van verantwoordingen.

Getrouwheid omvat:

- de 'waarheid', de juistheid en volledigheid van de feiten die hun weerslag in de verantwoording dienen te vinden;

- de niet misleidende weergave van die feiten in de verantwoording.

De 'weergave' omvat de algemene keuze van het waarderingsstelsel, de schatting van specifieke onzekere elementen in de verantwoording, en de presentatie.

In de accountantscontrole moet de 'waarheid' worden vastgesteld en de weergave worden beoordeeld.

De 'waarheid' heeft twee kanten: juistheid en volledigheid. In het Angelsaksisch rechtsverkeer moeten getuigen zweren 'the truth, the whole truth (volledigheid!) and nothing but the truth (juistheid!)' te vertellen. Dus zijn juistheid en volledigheid belangrijke controledoelstellingen. Zij zijn echter niet specifiek genoeg om een goede uitvoering van de controle te waarborgen. Zo moet bij het onderzoek naar de juistheid van de verantwoording van voorraden worden vastgesteld of de voorraden bestaan c.q. aanwezig zijn, of zij eigendom van de gecontroleerde zijn, of de bij de omrekening in geld gebruikte prijzen correct zijn, of de omrekening en de optelling accuraat zijn uitgevoerd, en ten slotte of de waardering moet worden aangepast wegens onverkoopbaarheid. De belangstellende lezer zal in het voorgaande vele van de door Ten Wolde geïntroduceerde controledoelstellingen hebben teruggevonden.

Om operationeel bruikbaar te zijn, moet de controledoelstelling 'juistheid' dus in factoren ont-

Prof. J. H. Blokdijk, registeraccountant, is lid van de maatschap KPMG Klynveld accountants. Hoogleraar Accountantscontrole aan de Vrije Universiteit Amsterdam. Heeft vele vaktechnische functies bij het NIvRA vervuld. 
bonden worden; ditzelfde zal bij de controledoelstelling 'volledigheid' vaak evenzeer nodig zijn. Dit heeft Ten Wolde dan ook gedaan. Maar dit betekent nog niet dat het zinvol zou zijn de begrippen 'juistheid' en 'volledigheid' nu maar uit de theorie en uit de praktijk te verwijderen. Zij liggen op een hoger abstractieniveau dan het door Ten Wolde genoemde zestal; zij spelen dus ook een rol bij werkzaamheden van een hoger niveau, en wel het maken van het controleplan. Zij bepalen met name de richting van de controle, en zijn vooral bij bijzondere onderzoekingen, waarvan de doelstellingen sterk kunnen variëren, onontbeerlijk bij het ontwerpen van de aanpak van het onderzoek; daarbij komen de begrippen 'positieve' en 'negatieve' controle dan ook intensief aan de orde.

De hoofddoelstellingen 'volledigheid' en 'juistheid' bepalen het controleplan, de gedetailleerde controledoelstellingen van Ten Wolde beheersen de vaststelling van het werkprogramma, de gedetailleerde werkinstructies. Theoretisch vormen 'juistheid' en 'volledigheid' de schakel tussen het zestal van Ten Wolde en het hoge ideaal van 'getrouwheid'.

\section{Controledoelstellingen in de praktijk}

Het uiteenrafelen van de 'hogere' doelstellingen van juistheid en volledigheid is dus nodig om deze operationeel te maken, om er in de praktijk mee te kunnen werken. Dat moet dus zo handig, zo doelmatig mogelijk geschieden; Ten Wolde benadrukt terecht dat assistenten er gemakkelijk mee uit de voeten moeten kunnen. Wordt dit met Ten Woldes zestal ook bereikt? Daarbij zijn enkele kritische kanttekeningen te maken.

In de eerste plaats presenteert Ten Wolde de controledoelstellingen 'waardering' en 'presentatie' als elementen van 'juistheid en volledigheid'. Zij vallen echter niet onder het begrip 'waarheid', maar onder 'weergave'; zij behoren dan ook niet tot de controledoelstellingen 'juistheid' en 'volledigheid', en hebben geen betrekking op de begrippen 'positieve' en 'negatieve' controle. Wel is het in de praktijk handig alle controledoelstellingen in één rij mee te nemen.
Dit is dus geen kritiek op Ten Woldes praktische oplossing, maar wel op zijn schets van het theoretische bouwwerk.

Kritiek op de praktische aanpak kan wel worden gegeven naar aanleiding van een andere door Ten Wolde gegeven controledoelstelling: accuratesse. Wanneer men deze doelstelling toepast op het door mij in de vorige paragraaf gegeven voorbeeld van de controle van voorraden, dan blijkt 'accuratesse' uiteen te vallen in:

- zijn de hoeveelheden van de bij inventarisatie aangetroffen voorraden correct in de op de jaarrekening aansluitende voorraadspecificatie opgenomen?

- zijn de daarin opgenomen prijzen correct, mede in verband met het gekozen systeem (bijvoorbeeld fifo, gemiddelde inkoopprijs, laatst bekende inkoopprijs)?

- zijn de omrekeningen en is de telling correct?

Het vereist dus enige analyse om vast te stellen wat nu eigenlijk allemaal onder de doelstelling 'accuratesse' valt. Bovendien zullen deze werkzaamheden lang niet altijd door assistenten van hetzelfde niveau verricht kunnen worden; zij zullen dus menigmaal door verschillende personen worden uitgevoerd. Het lijkt dan niet handig deze verschillende werkzaamheden onder één noemer 'accuratesse' samen te vatten.

Om controledoelstellingen operationeel te maken, zouden deze nog iets verder ontleed en van meer praktijkgerichte benamingen voorzien moeten worden.

Soortgelijke kritiek is mogelijk op grond van een door Ten Wolde gegeven voorbeeld van een instructie: 'Stel het bestaan van de kortingen vast' (p. 302). Letterlijk genomen is deze instructie eenvoudig: in de verkoopvoorwaarden is snel te zien dat de onderneming kortingen geeft. Maar wat is de echte vraag: 'zijn de als korting verantwoorde bedragen wel kortingen, of eigenlijk vermomde uitgaven?' en/of: 'zijn de verleende kortingen wel terecht gegeven?' en/of andere vragen? De doelstelling 'bestaan', die bij activa zo duidelijk is, is bij posten in de resultatenrekening veel minder 


\section{MAB}

helder, en dus minder operationeel. lets dergelijks geldt voor de vraag: 'zijn de uitgaven zakelijke kosten of privébestedingen van de directeur/aandeelhouder?' Voor posten in de resultatenrekening zou de doelstelling 'bestaan' dus een of meer andere etiketten moeten hebben.

Om controledoelstellingen echt operationeel te maken, zouden dus verschillende benamingen moeten worden gekozen voor de doelstellingen bij de controle van de resultaten en van de balans, en voor deze laatste vermoedelijk nog verschillende etiketten bij activa en bij passiva.

\section{Conclusies}

De gedachte om beweringen en controledoelstellingen nader te analyseren levert stellig een verrijking van de theorie op. De tot dusverre gehanteerde controledoelstellingen 'juistheid' en 'volledigheid' moeten echter niet worden afgeschaft, maar op het juiste niveau worden geplaatst: het controlepan. Voor het werkprogramma, de concrete gedetailleerde instructies, dienen de door Ten Wolde gegeven controledoelstellingen nader onderscheiden en praktischer geëtiketteerd te worden. 